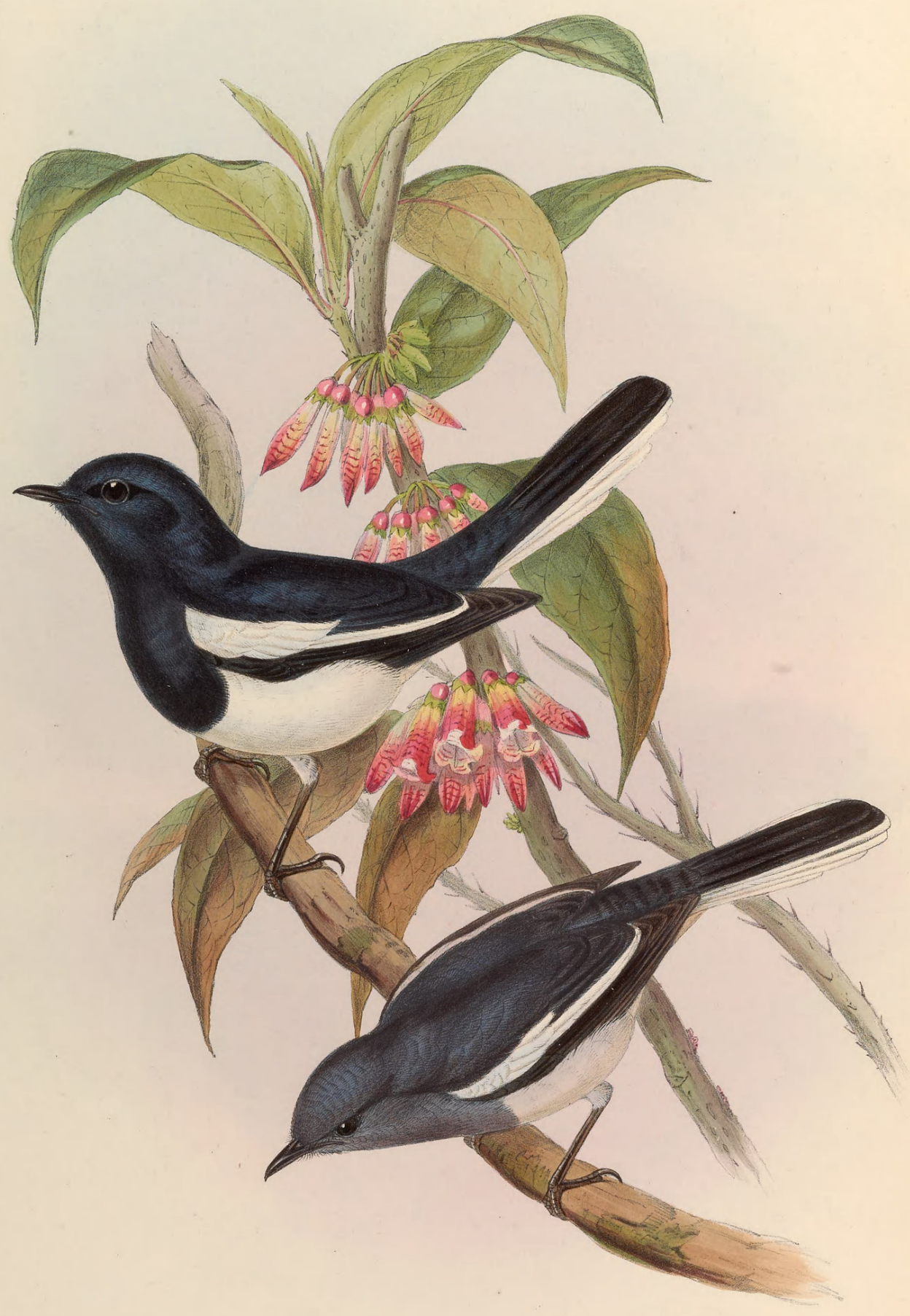

COPSYCHUS SAULARIS。 


\section{COPSYCHUS SAULARIS.}

\section{Dial Bird.}

Gracula saularis, Linn. Syst. Nat., tom. i. p. 165.-Ib. Gmel. edit., tom. i. p. 397._Lath. Ind. Orn., vol. i. p. 192 Stermus saularis, Daud. Orn., tom. ii. p. 321.

Lanius Bengalensis niger, Briss. Orn., tom. ii. p. 184.

Copsychus saularis, Wagl. Syst. Av., sp. -Blyth, Journ. Asiat. Soc. Beng., vol. xi. p. 889, vol. xvi. p. 139.Id. Cat. of Birds in Mus. Asiat. Soc. Calcutta, p. 166.-Gray and Mitch. Gen. of Birds, vol. i. p. 177 -Gray, Cat. of Spec. and Draw. of Mamm. and Birds pres. to Brit. Mus. by B. H. Hodgson, Esq. p. 67.-Bonap. Consp. Gen. Av., tom. i. p. 267.-Layard, Ann. Nat. Hist., 2nd ser. vol. xii. p. 263 -Horsf. and Moore, Cat. of Birds in Mus. East Ind. Comp., vol. i. p. 275, - Sclat, in Proc, of Zool. Soc. 1861, p. 186.-Swinh. in Ibis, vol, ii. p. 54.

Gryllivora intermedia, Jerd. Madras Journ. of Lit. and Sci., vol. x. p. 263.

Dahila docilis, Hodgs. Asiat. Res., vol. xix. p. 189

Kittacincla melanoleuca, Less. Rev. Zool. 1840, p. 354.

Fringilla nigra, Klein, Av., p. 98.

The Little Indian Pye, Edw. Nat. Hist. of Birds, part iv. pl. 181

Dial Grakle, Lath. Gen. Syn., tom. ii. p. 265; Supp., p. 91.-Marsd. Hist. of Sumatra, p. 98.-Lath. Gen. Hist., vol. iii. p. 165

Magpie Robin, English in Ceylon, Layard.

Dayal, Beng., Harnilton, Blyth.

Day-yur or Deyr, Hind, Jerdon.

Polichia, Cing., Layard.

Caravy cooroori, "Charcoal Bird," Mal., Layard.

Chuy-kam-chay, at Amoy, Swinhoe.

To say that the "voice of song" is denied to the birds of India would be untrue ; for that favoured land, as well as most others, comprises some beautiful musicians among its ornithological productions; and the Shama, the Dayal, and the Bulbul of India are scarcely inferior in musical powers to the celebrated MockingBird of America, or our own no less celebrated Nightingale. So conspicuous in this respect is the present bird that it has attracted the notice of nearly every writer on the birds of India ; and I cannot do better than give a transcript of the interesting accounts they have placed on record.

"The Dayal," says Mr. Jerdon, "is generally spread throughout India, and frequents jungles, gardens, avenues, topes, \&c. It is solitary, frequenting thick trees and bushes; feeds on the ground, flying down from a low branch (its usual perch), and frequently hopping a few steps on the ground, jerking its tail well up every now and then. On securing an insect, it flies back to its perch, elevating its tail on reseating itself, and uttering a pleasant warble. Towards evening, it may often be seen near the top of some lofty tree in the jungle, pouring forth its agreeable song, which, however, must yield the palm to the Shama."

Captain Hutton states that it "arrives on the hills, up to 5000 feet, in the beginning of April. It returns to the Doon and the plains in early autumn. It breeds in May, on the 19th of which month I took a nest from a bank by the roadside; it was composed of green mosses, and lined with very fine roots. Eggs four, carneous cream-colour, somewhat blistered at the larger end; diameter $\frac{12}{16} \times \frac{8}{16}$ in. Delights to sit on the topmost branches of a tree, generally selecting a dry and leafless twig, from whence it utters a pleasing song, which is replied to by another individual at no great distance. When on the ground, it hops with the wings half open or drooping, and at each hop it stops to jerk and spread its tail."

Mr. Hodgson informs us that "The Dayals, if found in the wilds, tenant meadows and grass-land provided with brushwood; but they are nowhere so common as in gardens and on lawns, which they enliven in spring by their song, and at all times by their vivacity and familiarity. They dislike and avoid the interior of woods. Their usual food is grubs, worms, beetles, grasshoppers, and their congeners ; rarely, in winter, they take unripe vetches and such like, but never gravel, sand, or hard seeds. They move quickly on the ground, yet perch firmly and readily, frequently watching for their prey on a low twig, to which they return as soon as they have beaten it to death on the ground. They never seize on the wing. When cattle pass their way, they will partially attend on the herd, descending occasionally from their perch to snatch up the insects and grubs brought to light by the act of grazing. These birds are perpetually in motion, and raise and depress the body, with flirtation of the tail, exactly in the Wagtail manner. Their habits of society, in respect to their own kind, are solitary, or nearly so, except in the breeding-season, when these monogamous and attached birds steadily unite to rear and defend their young. The female usually lays five spotted eggs, bringing up from three to four young ones, and but once a year unless the first brood has failed or been rifled from her. The nest is carelessly made of grass, but is always placed in a secure and sheltered position- 
commonly a hole in a wall, sometimes the interior of a low, thick, prickly plant. The Dayal is one of the boldest and most docile of birds, and is perpetually caged, both for his song and his pugnacity. Few of the Thrushes have a finer note; nor is it degraded by apish tricks of imitation, though this intelligent bird will lend its courage for the profit or amusement of its keeper. In the spring the male birds are perpetually challenging each other, and no sooner is the defiance of one uttered than it is answered by another. The professional bird-keeper, availing himself of this propensity, takes out his tame male on his fist, and proceeds to the nearest garden or grove; the bird, at his bidding, presently challenges; the wild one immediately answers: the former is then slipped, and a desperate contest ensues between the two, during which the fowler readily secures the wild bird, with the tame one's assistance; for the latter will deliberately aid his owner's purpose, seizing the wild bird at the critical moment with both claws and bill, and retaining it till his master comes up, in case it has not been so much exhausted by the previous contest as to be disabled from flying away at the man's approach. Fighting the tame birds is a favourite amusement with the rich, nor can any race of game-cocks contend with more energy and resolution than do these birds.'

Mr. Layard informs us that, in Ceylon, "this familiar household bird is called the 'Magpie-Robin' by Europeans; and the natives regard it with as much interest as we do our own red-breasted favourite, of which it is the Eastern representative. It is seldom seen away from habitations, about which it usually builds, though the nest is often placed in a thick bush or hollow tree. The eggs, commonly four in number, are bright blue, thickly spotted with brown at the obtuse end. The food is insects, of all kinds and in all stages, captured on the ground and on trees. They have a variety of notes, and the song poured out in the fulness of their joy in the pairing-season is very pleasing. On the top of a towering cotton-tree, opposite my residence in Colombo (in Ceylon), a Magpie-Robin daily for some weeks charmed me with its song, whilst his mate sat brooding her eggs or callow nestlings in the roof of a native hut beneath him. One morning, after the young had left the nest and betaken themselves to the neighbouring compounds, I was attracted by cries of distress from various birds and squirrels, and, above all, I heard the seemingly plaintive mewing of a cat. I had no living specimen of the last in my museum; so, wondering what could be the matter, went into my garden to see. I found the mewing proceeded from my friends the Robins, who were furiously attacking something in a bush, whilst the birds and squirrels screamed in concert. There I found one of the young Robins (whose plumage, by the way, at that early age, much resembles that of the European bird, being speckled with yellow) caught, as I thought, in the tendrils of a creeper. I put out my hand to release it, when, to my surprise, I saw the glittering eyes of the green whip-snake (Trimesurus viridis, Lacép.), in whose fangs the bird was struggling. I seized the reptile by the neck and rescued the bird, but too late; it lay panting in my hand for a few moments, then fluttered and died. On skinning it, I found no wound, except on the outer joint of the wing by which it had been seized, and am confident that fear alone deprived it of life. A favourite attitude of this bird is, standing with the tail elevated over the back, either perpendicularly or thrown so much forward as to nearly touch the head, the wings drooping; in this position they only utter a low note. During the dry season some of our birds become so discoloured with the dust of our red Kabook soil, that they are useless as specimens for preserving."

Latham states that this species " is one of those birds which are used when inroking the name of God a custom which those of India have borrowed of the Hindoos. Dr. Buchanan adds that at Calcutta it is commonly called Doil by the Bengalese; in Persia, Dahool or Dahale, and there kept only for its song. It makes an artless nest of sticks and hair on the branches of trees; the eggs pale greenish blue, with brown spots, most numerous at the large end."

"This very sprightly bird," says Capt. Boys, "frequents the trees and bushes of the gardens, and, like the English Robin, carries its tail very erect, which gives it a bold appearance. It is very familiar, and has a sweet note. Its food consists of insects; and it builds in the chinks and holes of walls, forming its nest of small dry twigs and grass roots, and laying five greenish-blue eggs, blotched all over with brown, but mostly at the larger end.

"Specimens obtained at Sultanpore, December 8, 1839 ; and a nest at Almorah, May 28, 1842."

Mr. Swinhoe says it is "a common resident" at Amoy.

The male has the head, all the upper surface, throat, chest, and upper portion of the abdomen steely black; wings dull black, with the exception of the upper rows of coverts and the margins of several of the secondaries, which are pure white, forming a conspicuous stripe along the wing; three outer tail-feathers white ; the next on each side white, broadly margined on the inner web for five-sixths of its length from the base with deep black, which is also the hue of the remaining tail-feathers, lower half of the abdomen and under tail-coverts white; irides brown; bill and legs black.

The female differs in having the upper surface dark grey, washed on the back with steel blue, the face, throat, and chest grey, the wings brown, the white mark on the wing less conspicuous, the black of the tail much less intense, and the white of the abdomen washed with greyish buff.

The Plate represents both sexes, of the size of life. The plant is the Thibaudia pulcherrima. 


\section{$2 \mathrm{BHL}$ Biodiversity Heritage Library}

Gould, John. 1863. "Dial Bird, Copsychus saularis [PI. 24]." The Birds of Asia 3(XV), -. https://doi.org/10.5962/p.323303.

View This Item Online: https://www.biodiversitylibrary.org/item/118635

DOI: https://doi.org/10.5962/p.323303

Permalink: https://www.biodiversitylibrary.org/partpdf/323303

\section{Holding Institution}

Smithsonian Libraries

\section{Sponsored by}

Smithsonian Institution Libraries

\section{Copyright \& Reuse}

Copyright Status: Not in copyright

This document was created from content at the Biodiversity Heritage Library, the world's largest open access digital library for biodiversity literature and archives. Visit BHL at https://www.biodiversitylibrary.org. 